\section{EDUCATION}

Research, Innovation and Solutions on-line ${ }^{(0)}$
Electronic Journal of Research

in Educational Psychology

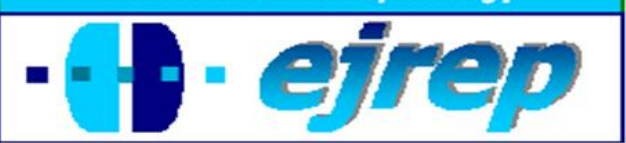

Editorial EOS

\title{
Attributional style of children with and without Specific Learning Disability
}

\section{Tiziana Pasta, Manuela Mendola, Claudio Longobardi, Laura Elvira Prino, Francesca Giovanna Maria Gastaldi}

Department of Psychology, University of Turin

Italy

Correspondence: Claudio Longobardi. Department of Psychology, University of Turin, Via Po 14, 10123, Torino, Italy. E-mail: claudio.longobardi@unito.it

(C) Education \& Psychology I+D+i and Editorial EOS (Spain) 


\section{Abstract}

Introduction. The literature highlights that pupils with Specific Learning Disability (SLD) often reveal a poor meta-cognitive system, with low levels of attribution to internal factors like diligence and personal skills, and high levels of attribution to external factors like ease of task, luck or help from others.

Method. This study aims to analyze the attributions expressed in the school context by pupils diagnosed with Specific Learning Disability ( $\mathrm{N}=38$; Age in months: Mean=100.24; $\mathrm{SD}=5.828)$ and to compare them with those by children without learning disabilities $(\mathrm{N}=70$; 38 of them with the same academic achievements as the pupils with SLD, and 32 with opposite achievement levels). The instruments are the Attribution Test 4-10 years, nationally validated learning tests and the Student-Teacher Relationship Scale.

Results. The analysis shows that just the pupils with SLD do not have an attributive style of the "strategic effort" kind, and, among them, the children that obtain the best scores in the nationally validated learning tests are the ones who least often, especially in cases of success, choose the ability factor and most often choose luck as the cause. Considering the teachers' perceptions of the relationship between the pupils in the sample, the most significant score is related to Dependency: children with SLD are perceived far more dependent than their mates without SLD.

Discussion and Conclusion. Results show that SLD do not cause a disadaptive attributive style but it causes an higher level of Dependency on the teacher; these children, in fact, do not have such a strong, stable attributive style with internal locus, and are inclined to attribute their results also to factors outside their own person. As a result, they seem not aware of their potential and search help even when it is not necessary.

Keywords: teacher-child relationship, attribution (social psychology), learning disabilities, elementary school. 


\title{
Estilo atribucional de niños con o sin Dificultad Específica de Aprendizaje
}

\begin{abstract}
Resumen
Introducción. La literatura ha mostrado que los alumnos con Trastornos específicos del aprendizaje (TEA) se distinguen a menudo por un sistema metacognitivo carente con bajos niveles de atribución a factores internos, como el esfuerzo y las habilidades personales, y altos niveles de atribución a factores externos, como la facilidad de la actividad, la suerte y la ayuda por parte de terceras personas.
\end{abstract}

Método. El estudio realizado pretende analizar las atribuciones desarrolladas en un ámbito escolar por alumnos con Trastornos específicos del aprendizaje ( $N=38$; edad en meses: $\mathrm{M}=100,24 ; \mathrm{SD}=5,828)$ y compararlas con las de alumnos sin TEA $(\mathrm{N}=70$, de los cuales 38 con el mismo nivel de rendimiento de los alumnos con TEA y 32 con nivel de rendimiento opuesto). Los instrumentos utilizados son la Prueba de Atribución 4-10 años, pruebas de aprendizaje que han sido validadas a nivel nacional y la escala de relación profesor-alumno.

Resultados. Los análisis demuestran que los únicos que no tienen un estilo atributivo del tipo "esfuerzo estratégico" son los alumnos con TEA y que, entre ellos, los niños que consiguen las mejores puntuaciones en las pruebas de aprendizaje validadas a nivel nacional son los que eligen con menor frecuencia (especialmente en los casos de éxito) el factor habilidad y consideran sobre todo la suerte como causa principal. Si se considera la percepción que el docente tiene sobre la relación con los alumnos de la muestra, el resultado más significativo se refiere a la Dependencia: los niños con TEA son percibidos como mucho más dependientes respecto a sus compañeros sin TEA.

Discusión y Conclusión. Los resultados revelan que los TEA no causan un sistema atributivo desadaptativo, pero provocan un mayor nivel de dependencia hacia el maestro. De hecho, estos niños no tienen un estilo atributivo a locus interno tan fuerte y estable y son propensos a atribuir sus propios resultados a factores externos a su persona. Por consiguiente, todo parecer indicar que no son conscientes de su potencial y que solicitan más ayuda, incluso cuando no es necesaria.

Palabras Clave: atribución (psicología social), trastornos del aprendizaje, Educación Primaria, relación docente-alumno. 


\section{Introduction}

Attribution is defined as individuals' perception of the causes of the events that happen to themselves and others (De Beni \& Moè, 2000; Weiner et al., 1971). Since one's attributive style acts as an "indicator" of the perception one has of one's capacities and more generally of oneself, it is important to take into account the pupils' perception of the cause of their successes and failures in order to predict their behavioral and emotional tendencies especially when there are scholastic difficulties.

Some authors (Cornoldi, 2007; Ravazzolo, De Beni, \& Moè, 2005; Rogers \& Saklofske, 1985) reported that pupils with problems at school are more likely to develop disadaptive attributions, that is, to fail to recognize the role of effort, and instead tend to blame their repeated failures on their personal abilities. When faced with a positive result, they would tend to attribute the success to external factors such as help from others, luck or the easiness of the task, and not to recognize any merit in themselves. This would indicate the development of a strong sense of inefficacy (Bryan, 1986; Gans, Kenny, \& Ghany, 2003; Gonzàlez-Pienda et al., 2000; Pajares, 1996; Tabassam \& Grainger, 2002).

Considering that the presence of Specific Learning Disabilities (SLD) is believed to be a risk factor in scholastic failure (Stella \& Savelli, 2011), it could be supposed that the pupils affected are doomed to a negative school experience and to develop a "depressed" or "learned impotence" attributive style (Cornoldi \& Re, 2010; Tabassam \& Grainger, 2002; Tressoldi \& Vio, 2012). Some studies, however, show that the onset of a disadaptive attributive system does not involve all pupils that present SLD (Durrant, 1993; Gonzàlez-Pienda et al., 2000; Jacobsen, Lowery, \& Ducette, 1986; Nunez et al., 2005, 2011; Pintrich, Anderman, \& Klobucar, 1994; Roia, Lonciari, \& Carrozzi, 2008). It is important in any case to think about the possibility that the presence of an SLD constitutes a risk factor for the development of a weak and insecure sense of self-efficacy (identified with the recording of a disadaptive attributional style) since it can influence different aspects of the pupil's life, scholastic or otherwise. Moreover, beliefs about cognitive efficacy are reflected in social relations. Those who show a strong sense of self-efficacy towards schoolwork are more likely to be pro-social, receive fewer rejections than children that are unsure of their intellectual abilities and enjoy greater popularity in their peer group (Bandura, 1997). As far as the pupils with SLD are concerned, research carried out by Singer (2005) shows that the presence of specific reading dis- 
ability damages the pupils' self-esteem, both scholastic and personal. These pupils are more vulnerable and are often victims of bullying. According to Singer it is only the pupils' development of an adequate sense of self-efficacy, resulting from real effort to overcome their difficulties, that will gradually allow them to modify their self-concept and therefore improve their social relations.

In a systemic perspective (Pianta, 1999) for the real development of self-confidence, the subject must be able to rely on protective factors such as the support of parents, schoolmates and teachers. The latter, in particular, can act as "significant others" in the school environment (Sullivan, 1953), meaning they can be the people that exert a profound effect on the development of the Self, since they can foster or reduce the pupil's sense of well-being (Birch \& Ladd, 1997; Hamre \& Pianta, 2001). Some studies (Humphrey \& Mullins, 2002a, 2002b) confirm the influence of teachers as an important factor in the development of self-esteem in dyslexic children. In fact, it has now been demonstrated that it is necessary to study the relationship with the teacher in the years of primary school, the period when pupils build up important competences which prove decisive in the years that follow (Entwisle \& Hayduk, 1988; Ravazzolo et al., 2005). Often however teachers are not aware of the role played in guiding the pupils' attributions and in maintaining their motivation (Marini, 1991).

\section{Objectives}

Given these premises, the study reported here sets out to analyse whether the presence of difficulties caused by a Specific Learning Disability is associated with disadaptive styles of attribution. By comparing three groups of subjects (pupils with SLD, pupils without SLD whose achievement levels are equal to or opposite from their peers with SLD) and by administering objective achievement tests, the aim is also to see whether there is an association between low school achievement and disadaptive attribution styles, whether or not SLD is present.

Lastly, having recorded the class teachers' perception of the relationship experienced with each pupil, the connections will be highlighted between relational quality and attributive style found in subjects with or without SLD (with equal or opposite school achievement). 


\section{Method}

\section{Participants}

Pupils. A total of 108 pupils took part in the study (Age in months: $\mathrm{M}=100.03$; SD = 6.291), all in Years 2 and 3 at state primary schools in North-West Italy. All the subjects are Italian and do not have special education needs beyond those recorded for the purposes of the present study. The sample was divided into three groups (Table 1): an experimental group (EG) made up of 38 pupils with a Specific Learning Disability (diagnosed or with certification underway); the first control group (CG1) composed of the same number of pupils $(\mathrm{N}=$ 38) who show no learning disabilities but who have the same level of achievement as the pupils belonging to the EG; the second control group (CG2) of 32 pupils whose achievement level is the opposite of that of the pupils in the EG. The pupils' achievement levels was recorded by the main teacher in each class, with reference to Italian and Math, using a threepoint Likert scale (low, medium, high). The sample was mainly male (58.3\%).

The Control Group pupils were drawn at random amongst the peers of the children with SLD, provided they had their parents' permission and the required characteristics (in terms of school achievement and membership of the category). $98.6 \%$ of the members of the EG (and therefore CG1) showed a low or a medium level of school achievement. The EG pupils mainly $(\mathrm{N}=34)$ showed difficulty in the literacy area (reading, writing, or text comprehension). Only one pupil had specific difficulties in numeracy, while three showed mixed SLD.

Table 1. Characteristics of pupils in EG, CG1, and CG2

\begin{tabular}{lcccccc}
\hline Groups & $\begin{array}{c}\mathrm{N} \\
\text { Total }\end{array}$ & $\begin{array}{c}\mathrm{N} \\
\text { Boys }\end{array}$ & $\begin{array}{c}\mathrm{N} \\
\text { Girls }\end{array}$ & $\begin{array}{c}\mathrm{N} \\
\text { Year } 2\end{array}$ & $\begin{array}{c}\mathrm{N} \\
\text { Year 3 }\end{array}$ & $\begin{array}{c}\text { Age in } \\
\text { months } \\
\text { Mean }(S D)^{*}\end{array}$ \\
\hline EG & 38 & 23 & 15 & 16 & 22 & 100.24 \\
CG1 & 38 & 20 & 18 & 16 & 22 & $\begin{array}{c}(5.828) \\
\text { CG2 }\end{array}$ \\
\hline
\end{tabular}

\footnotetext{
*Note: Among the three groups there are no statistically significant differences regarding age.
} 
Teachers. When possible, the two main teachers (Italian and Maths) of each class took part in the study. In four classes there was a "single teacher". In total 35 teachers were involved: 17 of Italian, 14 of Mathematics and 4 "sole" teachers.

\section{Instruments}

In order for their attributive style to be identified, the pupils did the Attribution test for children from 4 to 11, designed by De Beni, Moè and Ravazzolo (1998). In the test the children are presented with some hypothetical situations of daily or school life which they may have encountered. Each situation is followed by five possible causes that can be attributed to the event and for each one the subject is invited to choose two responses, ranking them in order of importance. The possible answers were related to the causes recognized in the literature as being the most frequent in moments of success and failure (Weiner, 1985): personal effort or lack of effort (internal, unstable, controllable cause), ability or non-ability (seen as a fixed characteristic of intelligence, an internal, stable, uncontrollable cause), the easiness or difficulty of the task (external, stable, uncontrollable cause), help or lack of help from others (external, unstable, uncontrollable cause), good luck or bad luck (external, unstable, uncontrollable cause). The analysis took into account the scores obtained for each single "alternative cause", both by considering the situations of success and failure separately (range 0-8), and together (range 0-16).

In order to measure the teacher's perception of the quality of the relationship experienced with every single pupil, use was made of the Student-Teacher Relationship Scale (Pianta, 2001) in the Italian version elaborated by Fraire et al. (in press). This scale assesses three relational dimensions: Conflict, Closeness and Dependency (teoric range: Conflict 1050; Closeness: 8-40; Dependency: 4-20). High scores in the sub-scale related to Conflict suggest that problem behavior by the student during lessons is the cause of a negative emotional climate; the teacher perceives the pupil as angry and unpredictable but is unable to control the pupil's feelings and their manifestations, making him/her feel ineffective and frustrated. The Closeness dimension on the other hand evaluates the positive emotional aspects of the relationship. If the relationship is marked by mutual trust and good communication, the teacher perceives him/herself as a support for the pupil, to be relied on in moments of difficulty. The sub-scale of Dependency shows whether the teacher assesses the pupil as overly dependent on him/her in doing any activity; in this case the teacher is convinced that the pupil asks for help too often and demands attention even when it is not appropriate to do so. 
The scholastic level of the children participating in the research was measured through Nationally Validated Standardized Achievement tests in Italian and Mathematics. For Italian the tests used were designed to check reading accuracy and speed, reading comprehension (Cornoldi \& Colpo, 1998) and word dictation (Giovanardi Rossi \& Malaguti, 1994a). The Math tests were taken from the test battery "Assessment of mathematical abilities" designed by Giovanardi Rossi and Malaguti (1994b) and concerned exercises on sequencing, classification, written additions and subtractions and problem solving.

\section{Procedure}

\section{Statistical Analysis}

The data analysis was carried out using the statistical software IBM SPSS 20.0. The differences in attributive style between the experimental group and the control group were anlysed using ANOVA and Student's T test. Afterwards, an analysis was made of the correlations between attributional choice and achievement test scores. As regards the quality of the relationship perceived by the teacher, a study was made of the differences between the groups using ANOVA and the correlations with attributive style.

\section{Results}

Attributive style prevailing in the three groups in the sample

Considering the scores given by the sample's three groups of pupils to the causes of situations involving success and failure, it emerges that for the pupils of all three sub-groups the first cause chosen was effort, an internal cause, unstable but controllable. However, while the CG2 pupils (with mainly high achievement) on average gave personal effort a score of $10.74(\mathrm{SD}=2.72)$ and the lowest score given was 6 , the pupils with SLD gave effort an average score of 6.68 ( $\mathrm{SD}=3.53$ ) and some members of the group never chose this type of cause (see Tab. 2). The analysis of Student's t-distribution confirms the statistically significant difference between the EG pupils and those in the control groups concerning the frequency with which effort was chosen as the general cause of their successes and failures $(t(105)=3.852, p$ $<.001)$. This difference is especially evident between EG and CG2 $(F(2,104)=12.567, p<$ .001). Moreover, for the EG pupils the choice of effort as the first cause is closely followed by easiness of task $(M=6.34, S D=2.80)$. The EG subjects in fact also differ in a statistically 
significant way from the CG pupils in the frequency of their choice of easiness of task ( $t$ (105) $=3.244, p<.005$ ). For the CG1 pupils, too (without SLD, but with achievement equal to the EG) easiness of task, an uncontrollable external cause, is the second cause chosen $(M=5.26$, $S D=2.82)$. The second choice of CG2 children, on the other hand, is ability $(M=6.13, S D=$ 2.40); easiness of task appears as the third choice (Tab. 2).

Finally, the EG pupils differ from those in CG2 as regards the statistically higher scores given to the presence (in cases of success) or absence (in cases of failure) of luck ( $F$ (2, $104)=5.440, p<.01)$ and for the lower scores given to the personal ability factor $(F(2,104)$ $=3.977, p<.05)$.

Table 2. Means (Standard Deviation), minimum and maximum of Attribution total scores (Positive and Negative) obtained in the five alternatives for EG, CG1, and CG2

\begin{tabular}{lcccc}
\hline $\begin{array}{l}\text { Cause of } \\
\text { Attribution }\end{array}$ & $\begin{array}{c}\text { EG } \\
\text { (pupils with SLD) }\end{array}$ & $\begin{array}{c}\text { CG1 } \\
\text { (no SLD, equal } \\
\text { achievement) }\end{array}$ & $\begin{array}{c}\text { CG2 } \\
\text { (no SLD, opposite } \\
\text { achievement) }\end{array}$ & F-Fisher \\
\hline Effort** & $6.68(3.53)$ & $8.29(3.62)$ & $10.74(2.72)$ & $12.576^{\circ 0}$ \\
& $0-12$ & $1-14$ & $6-16$ & \\
Ability & $4.63(2.20)$ & $4.74(2.61)$ & $6.13(2.40)$ & $3.977^{\circ}$ \\
Easiness of & $0-9$ & $0-9$ & $2-10$ & \\
task** & $6.34(2.80)$ & $5.26(2.82)$ & $3.77(2.04)$ & $8.263^{\circ \circ}$ \\
Luck* & $2-14$ & $1-12$ & $0-8$ & \\
& $3.92(3.36)$ & $3.55(2.95)$ & $1.81(1.54)$ & $5.440^{\circ \circ}$ \\
Help & $0-13$ & $0-12$ & $0-5$ & \\
& $2.45(2.67)$ & $2.16(2.16)$ & $1.55(1.80)$ & 1.374 \\
\hline
\end{tabular}

Statistically significant differences between EG and CG $(* * p<.01 ; * p<.05)$.

Statistically significant differences between EG, CG1, and CG2 $\left({ }^{\circ} p<.01 ;{ }^{\circ} p<.05\right)$.

By distinguishing between the causes chosen for situations of success (Tab. 3) and those chosen for failure (Tab. 4), it emerges that the EG pupils, compared to their peers, more often attribute their successes to the easiness of task $(t(105)=3.054, p<.005)$ and more often than the CG2 pupils, choose difficulty of task as the first cause of failures, an uncontrollable external cause $(\mathrm{F}(2,104)=3.593, p<.05)$. Both in situations of success and of failure, the EG pupils recognize the importance of the effort made, albeit to a lower degree than their peers in the CG (situations of success: $t(105)=3.454, p<.005$; situations of failure: $t(105)=$ $2.789, p<.01)$. 
It is interesting to see that for situations of success, low achieving pupils without SLD (CG1) give scores that are "in the middle" between those given by children with SLD and those given by CG2 pupils to the causes effort $(F(2,104)=8.325, p<.001)$, ability $(F(2$, $104)=3.793, p<.05)$ and easiness of task $(F(2,104)=6.170, p<.01)$.

Table 3. Means (Standard Deviation), minimum and maximum of the Attribution scores obtained for the five alternative causes in situations of Success, for EG, CG1, and CG2

\begin{tabular}{lcccc}
\hline $\begin{array}{l}\text { Cause of At- } \\
\text { tribution }\end{array}$ & $\begin{array}{c}\text { EG } \\
\text { (pupils with SLD) }\end{array}$ & $\begin{array}{c}\text { CG1 } \\
\text { (no SLD, equal } \\
\text { achievement) }\end{array}$ & $\begin{array}{c}\text { CG2 } \\
\text { (no SLD, opposite } \\
\text { achievement) }\end{array}$ & F-Fisher \\
\hline Effort** & $3.39(1.79)$ & $4.29(1.80)$ & $5.25(2.00)$ & $8.325^{\circ \circ}$ \\
Ability & $0-7$ & $1-8$ & $2-8$ & $3.88(1.96)$ \\
Easiness of & $2.42(1.72)$ & $2.68(1.74)$ & $0-7$ & $3.793^{\circ}$ \\
task** & $0-7$ & $0-6$ & $1.39(1.28)$ & $6.170^{\circ \circ}$ \\
Luck & $2.66(1.68)$ & $2.00(1.47)$ & $0-5$ & \\
& $0-6$ & $0-5$ & $1.32(1.42)$ & $5.222^{\circ}$ \\
Help & $2.66(2.12)$ & $2.50(1.83)$ & $0-5$ & \\
\hline
\end{tabular}

Statistically significant differences between EG and CG $(* * p<.01 ; * p<.05)$.

Statistically significant differences between EG, CG1, and CG2 $\left({ }^{\circ} p<.01 ;{ }^{\circ} p<.05\right)$.

Table 4. Means (Standard Deviation), minimum and maximum of the Attribution scores obtained for the five alternative causes in situations of Failure, for EG, CG1, and CG2

\begin{tabular}{lcccc}
\hline $\begin{array}{l}\text { Cause of } \\
\text { Attribution }\end{array}$ & $\begin{array}{c}\text { EG } \\
\text { (pupils with } \\
\text { SLD) }\end{array}$ & $\begin{array}{c}\text { CG1 } \\
\text { (no SLD, equal } \\
\text { achievement) }\end{array}$ & $\begin{array}{c}\text { CG2 } \\
\text { (no SLD, oppo- } \\
\text { site achievement) }\end{array}$ & F-Fisher \\
\hline Lack of effort ** & $3.29(2.50)$ & $4.00(2.78)$ & $5.52(1.67)$ & $7.495^{\circ 0}$ \\
& $0-8$ & $0-8$ & $2-8$ & \\
Lack of ability & $2.21(1.45)$ & $2.05(1.49)$ & $2.55(1.57)$ & 0.956 \\
Difficulty of task & $0-5$ & $0-5$ & $0-6$ & \\
\multirow{2}{*}{ Bad luck } & $3.60(2.07)$ & $3.26(2.24)$ & $2.39(1.65)$ & $3.593^{\circ}$ \\
& $0-8$ & $0-7$ & $0-6$ & \\
Lack of help & $1.26(1.87)$ & $1.05(1.59)$ & $0.48(0.77)$ & 2.340 \\
& $0-6$ & $0-7$ & $0-2$ & \\
& $1.55(2.14)$ & $1.63(1.75)$ & $1.06(1.21)$ & 0.996 \\
\hline
\end{tabular}

Statistically significant differences between EG and CG $(* * p<.01 ; * p<.05)$.

Statistically significant differences between EG, CG1, and CG2 $\left({ }^{\circ} p<.01 ;{ }^{\circ} p<.05\right)$.

Relation between scores in standardized achievement tests and scores on attributive cause

Through the analysis designed to correlate the standardized achievement test scores with the scores given to each attributive cause, this study shows that the more the pupil attributes his results to effort, the fewer errors he/she makes in word dictation $(r=-.277, p<.01)$, 
number dictation $(r=.235 ; p<.05)$ and in tests of correct interpretation of passages $(r=-$ $.295, p<.01)$, the more he reduces reading times, i.e. increasing speed in seconds per syllable $(r=-.253, p<.01)$ and the better he performs in calculations $(r=.235, p<.01)$ and problem solving $(r=.400, p<.01)$.

On the other hand, the attributional dimension of help seems inadequate for the development of the abilities required in tests of correct interpretation of passages $(r=.206, p<$ $.05)$, speed reading $(r=.216, p<.05)$, number dictation $(r=-.236 ; p<.05)$ and problem solving $(r=-.244 ; p<.05)$.

Finally, the correlation analysis showed statistically significant results for the dimension of easiness/difficulty of the task. The greater the tendency to attribute one's performance to the characteristics of the test, the worse the results in tests of reading comprehension $(r=-$ $.226, p<.05)$, sequencing of figures and numbers $(r=-.190, p<.05)$, reading numbers $(r=-$ $.305, p<.01)$ and problem solving $(r=-.246, p<.05)$.

In repeating the analyses separately for each of the three groups in the sample, some differences are found. The children of the EG that obtain the best scores in the tests are the ones who least often, especially in cases of success, choose the ability factor and most often choose luck as the cause. On the other hand, the pupils of the two control groups that obtain the best scores in the tests tend to attribute an internal locus to the causes of their success.

Connection between attributive style and teacher's perception of the relationship with the pupils (STRS)

Considering the teachers' perceptions of the relationship between themselves and the pupils in the sample, it emerges that while the levels of Closeness and Conflict do not differ in the relationships with the children in the three groups, the average score for Dependency attributed to the EG pupils is from the statistical point of view significantly $(F(2,189)=$ $14.252, p<.001)$ higher $(M=7.82, S D=3.424)$ than that of the CG1 $(M=6.16, S D=2.893)$ and of the CG2 $(M=5.06, S D=2.051)$.

In general, considering the sample as a whole, the relationship perceived by the teacher is influenced by the attributive style: teachers perceive more conflictual $(F(2,189)=$ 
4.183, $p<.05)$ and dependent $(F(2,189)=6.767, p<.01)$ relationships with pupils that have an external locus of control instead of an internal one. In particular, the more a pupil attributes his/her results to effort, the more the teacher perceives an independent relationship with $\operatorname{him} /$ her $(r=-.281, p<.01)$. In contrast, if the outcome of the task is attributed to its easiness $(r=-.226, p<.01)$ and if failure is blamed on the lack of help received $(r=-.266, p<.01)$ or on the difficulty of the task $(r=.162, p<.05)$, the teacher perceives the relationship as more dependent. This correspondence between attributive style and relational quality is found, however, mainly in CG2 (high achieving pupils without SLD), while with reference to EG and CG1 subjects no significant differences were found in the teacher's perception of the relationship with the child in terms of whether the latter had an internal or external locus of control.

\section{Discussion and Conclusions}

The study found that pupils with SLD are not marked by a disadaptive attributive style and specifically do not present the "depressed" or "learned impotence" styles which in the literature some researchers associate with pupils whose learning difficulties are both general, and specifically caused by the presence of SLD. Effort, in fact, is the attributive option most often chosen both by EG pupils and by those in the CGs. Both in situations of success and in those of failure, pupils with SLD recognize the importance of the effort made, albeit to a lower degree than their peers in the control groups.

From the data however substantial differences emerge between the attributive choices of pupils with SLD and those without SLD with high school achievement. The pupils with SLD attribute far more importance to external, uncontrollable factors (like luck and the difficulty of the task) and have much less faith in their abilities and their personal effort if compared to the CG2 pupils who, by contrast, do not rely on luck or on the easiness of the task, but on their own abilities and in particular on the possibility of succeeding thanks to effort and perseverance. As a result, it emerges that the EG pupils, unlike the CG2 puplis, do not have an attributive style of the "strategic effort" kind (Ravazzolo et al., 2005). This type of style in fact envisages that the pupil attributes success primarily to effort and in part to ability, and attributes failure to lack of effort. 
Through the analysis designed to correlate the standardized achievement test scores with the scores given to each attributive cause, this study shows that the attributive style of the "strategic effort" serves for achievement (Bandura, 1997; Moè, De Cal, \& De Beni, 2002; Ravazzolo et al., 2005). The more the pupil attributes his results to effort, the fewer errors he/she makes in a lot of tests.

It is interesting to consider that while the pupils in the two control groups showed the correlations foreseen in the literature, i.e. children with better scholastic performance also tend to attribute an internal locus to the causes of their success or failure, while pupils with lower performance in achievement tests tend to choose causes connected to an external locus of control, the children with SLD do not follow the same direction in the correlations between scores in the attributive questionnaire and the objective achievement tests. The children of the EG that obtain the best scores in the tests are the ones who least often, especially in cases of success, choose the ability factor and most often choose luck as the cause. As a result, they seem not aware of their potentiat and this belief might determine the high level of Dependency perceived by the teachers in this study; it has been discovered, in fact, that the pupils in the EG make more requests for help even when it is not necessary. This Dependency on the teacher is associated primarily with a learning disorder and not with the medium-low school achievement that characterizes the EG pupils; in fact, it does not appear in the pupils of the control group with achievement levels equal to that of the children with SLD.

Furthermore the teacher's perception of Dependency related to EG pupils is not determined by their attributional style, in fact with reference to EG and CG1 subjects no significant differences were found in the teacher's perception of the relationship with the child in terms of whether the latter had an internal or external locus of control.

Overall, the data presented therefore attests to the fact that the EG pupils do not have such a strong, stable attributive style with internal locus, and are inclined to attribute their results also to factors outside their own person. The development of a sense of learned impotence reported as probable by the literature, could therefore occur. If such an attributive tendency should develop, these pupils could come to believe that they cannot change the outcome of situations and therefore give up making an effort, triggering a vicious circle leading to increasingly discouraging results followed by the loss of faith in their own capacities and in themselves. 


\section{References}

Bandura, A. (1997). Self-efficacy: The exercise of control. New York, NY: Freeman

Birch, S. H., \& Ladd, G. W. (1997). The teacher-child relationship and children's early school adjustment. Journal of School Psychology, 35(1), 61-79. doi:10.1016/S00224405(96)00029-5

Bryan, T. H. (1986). Self-concept and attributions of the learning disabled. Learning Disabilities Focus, 1(2), 82-89.

Cornoldi, C. (2007). Le difficoltà di apprendimento a scuola. Bologna: Il Mulino.

Cornoldi, C., \& Colpo, G. (1998). Prove di lettura MT per la scuola elementare. Firenze: Organizzazioni Speciali.

Cornoldi, C., \& Re, A. (2010). Metacognizione e componenti emotivo-motivazionali nei disturbi specifici dell'apprendimento. In S. Vicari, \& M. C. Caselli (Eds.), Neuropsicologia dello sviluppo. Bologna: Il Mulino.

De Beni, R., \& Moè, A. (2000). Motivazione e apprendimento. Bologna: Il Mulino.

De Beni, R., Moè, A., \& Ravazzolo, C. (1998). Sviluppo dello stile attributivo e relazione con le componenti metacognitive in bambini dai 4 ai 10 anni. Psicologia Clinica dello Sviluppo, 2(2), 245-269.

Durrant, J. E. (1993). Attributions for achievement outcomes among behavioral subgroups of children with learning disabilities. The Journal of Special Education, 27(3), 306-320. doi:10.1177/002246699302700303

Entwisle, D. R., \& Hayduk, L. A. (1988). Lasting effect of elementary school. Sociology of Education, 61(3), 147-159. doi:10.2307/2112624

Fraire, M., Longobardi, C., Prino L. E., Sclavo E., \& Settanni, M., (in press). Examining the Student-Teacher Relationship Scale in the Italian Context: A Factorial Validity Study.

Gans, A. M., Kenny, M. C., \& Ghany, D. L. (2003). Comparing the self-concept of students with and without learning disabilities. Journal of Learning Disabilities, 36(3), 285293. doi:10.1177/002221940303600307

Giovanardi Rossi, P., \& Malaguti, T. (1994a). Valutazione delle abilità di scrittura. Trento: Erickson.

Giovanardi Rossi, P., \& Malaguti, T. (1994b). Valutazione delle abilità matematiche. Trento: Erickson.

González-Pienda, J. A., Núñez, J. C., González-Pumariega, S., Álvarez, L., Roces, C., García, M., González, P., Cabanach, R. G., \& Valle, A., (2000). Autoconcepto, proceso de 
atribución causal y metas académicas en niños con y sin dificultades de aprendizaje. [Self-concept, causal attribution process and academic goals in children with and without learning disabilities]. Psicothema, 12(4), 548-556.

Hamre, B. K., \& Pianta, R. C. (2001). Early teacher-child relationships and the trajectory of children's school outcomes through eight grade. Child development, 72(2), 625-638. doi:10.1111/1467-8624.00301

Humphrey, N., \& Mullins, P. M. (2002a). Self-concept and self-esteem in developmental dyslexia. Journal of Research in Special Education Needs, 2(2). doi:10.1111/j.14713802.2002.00163.x

Humphrey, N., \& Mullins, P. M. (2002b). Personal constructs and attribution for academic success and failure in dyslexia. British Journal of Special Education, 29(4), 196-203. doi:10.1111/1467-8527.00269

Jacobsen, G., Lowery, B. Y., \& Ducette, J. (1986). Attributions of learning disabled children. Journal of Educational Psychology, 78(1), 59-64. doi:10.1037/0022-0663.78.1.59

Marini, F., (1991). Successo e insuccesso nello studio. La teoria attribuzionale della motivazione scolastica. Milano: Franco Angeli.

Moè, A., De Cal, C., \& De Beni, R. (2002). Motivazione ad apprendere e successo scolastico. Misurazione e relazione tra variabili in bambini di scuola elementare. Psicologia dell'educazione e della formazione, 3(4), 343-358.

Nunez, J. C., Gonzalez-Pienda, J. A., Gonzalez-Pumariega, S., Roces, C., Alvarez, L., Gonzalez, P., Cabanach, R. G., Valle, A., \& Rodriguez, S. (2005). Subgroups of Attributional Profiles in Students With Learning Difficulties and their Relation to Self-Concept and Academic Goals. Learning Disabilities Research and Practice, 20(2), 86-97. doi:10.1111/j.1540-5826.2005.00124.x

Núñez, J. C., González-Pienda, J. A., Rodríguez, C., Valle, A., Gonzalez-Cabanach, R., \& Rosário, P. (2011). Multiple Goals Perspective in Adolescents Students with Learning Difficulties. Learning Disability Quarterly, 34(4), 273-286. doi:10.1177/0731948711421763

Pajares, F. (1996). Self-efficacy beliefs in academic settings. Review of Educational Research, 66(4), 543-578. doi:10.2307/1170653

Pianta, R. C. (1999). Enhancing relationships between children and teachers. Washington, DC: American Psychological Association.

Pianta, R. C. (2001). Student-Teacher Relationship Scale: Professional Manual. Lutz, FL: Psychological Assessment Resources. 
Pintrich, P. R., Anderman, E. M., \& Klobucar, C. H. (1994). Intraindividual differences in motivation and cognition in students with learning disabilities. Journal of Learning Disabilities, 27(6), 360-370. doi:10.1177/002221949402700603

Ravazzolo, C, De Beni, R., \& Moè, A. (2005). Stili attributivi motivazionali. Percorsi per migliorare le capacità di apprendimento in bambini dai 4 ai 10 anni. Trento: Erickson.

Roia, A., Lonciari, I., \& Carrozzi, M. (2008). Disturbi specifici dell'apprendimento. Autostima e attribuzione in un gruppo di ragazzi che ha seguito un percorso riabilitativo. Dislessia. Giornale italiano di ricerca clinica e applicativa, 1, 19-31.

Rogers, H., \& Saklofske, D. E. (1985). Self-concepts, locus of control and performance expectations of learning disabled children. Journal of Learning Disabilities, 18(5), 273 278. doi:10.1177/002221948501800505

Singer, E. (2005). The strategies adopted by Dutch children with dyslexia to maintain their self-esteem when teased at school. Journal of Learning Disabilities, 38(5), 411-423. doi:10.1177/00222194050380050401

Stella, G., \& Savelli, E. (2011). Dislessia oggi: prospettive di diagnosi e intervento in Italia dopo la legge 170. Trento: Erickson.

Sullivan, H. S. (1953). Teoria interpersonale della psichiatria. Milano: Feltrinelli.

Tabassam, W., \& Grainger, J. (2002). Self-concept, attributional style and self-efficacy beliefs of students with learning disabilities with and without attention deficit hyperactivity disorder. Learning Disability Quarterly, 25(2), 141-151.

Tressoldi, P., \& Vio, C. (2012). Il trattamento dei disturbi specifici dell'apprendimento scolastico. Trento: Erickson.

Weiner, B. (1985). An attributional theory of achievement motivation and emotion, Psychological Review, 92(4), 548-573. doi:10.1037/0033-295X.92.4.548

Weiner, B., Frieze, I., Kulka, A., Reed, L., Rest, S., \& Rosenbaum, R. M. (1971). Perceiving the causes of success and failure. In E. E. Jones, D. E. Kanouse, H. H. Kelley, R. E. Nisbett, S. Valins, B. Weiner (Editors), Attribution: Perceiving the Causes of Behavior. (pp. 95-120). Morristown, NJ: General Learning Press. 